\title{
Minor changes in orthopteran assemblages of Central European protected dry grasslands during the last $\mathbf{4 0}$ years
}

\author{
Sebastian Schuch • Julian Bock • Christoph Leuschner • \\ Matthias Schaefer $\cdot$ Karsten Wesche
}

Received: 25 March 2010/Accepted: 17 January 2011/Published online: 15 February 2011

(C) The Author(s) 2011. This article is published with open access at Springerlink.com

\begin{abstract}
During the past 50 years development of farming practices caused tremendous changes in European agricultural landscapes and many insect species became increasingly restricted to protected areas. Yet little is known about long-term trends of insect diversity and community composition in these often small reserves. We performed a comparative study on changes in orthopteran communities of protected dry grasslands in East Germany, which had been surveyed in the 1960s. Applying the same sampling techniques, we revisited 26 of the original sites in 2008 and 2009. Nearly all sites are controlled by conservation policies and changes in vegetation composition were relatively small, although some sites showed shrub encroachment. Changes in orthopteran diversity were not significant. Community composition showed minor changes which were correlated with evidence of woody plant encroachment as derived from historical and recent aerial imagery. The frequency of some Caelifera species decreased from the 1960 s to $2008 / 2009$ with one species inhabiting bare soils
\end{abstract}

Electronic supplementary material The online version of this article (doi:10.1007/s10841-011-9379-6) contains supplementary material, which is available to authorized users.

S. Schuch $(\square) \cdot$ J. Bock $\cdot$ M. Schaefer

Animal Ecology, Johann-Friedrich-Blumenbach-Institute

of Zoology and Anthropology, Georg-August University

of Göttingen, Berliner Str. 28, 37073 Göttingen, Germany

e-mail: sschuch@gwdg.de

C. Leuschner

Plant Ecology, Albrecht-von-Haller-Institute for Plant Sciences,

Georg-August-University Göttingen, Untere Karspüle 2,

37073 Göttingen, Germany

K. Wesche

Senckenberg Museum of Natural History Görlitz,

PO Box 300 154, 02806 Görlitz, Germany
(Myrmeleotettix maculatus) showing the strongest decline. Some Ensifera, especially two species inhabiting open woodland and scrub (Tettigonia viridissima, Phaneroptera falcata) showed positive trends. Nevertheless, three different regions (each belonging to a different German federal state) had shown distinct orthopteran assemblages in the 1960 s, and these were equally different 40 years later. We conclude that the orthopteran fauna of Central European protected dry grasslands showed small changes in species composition, and overall diversity remained rather constant during the past 40 years, which is in accordance with the minor changes in the surrounding landscape. Consequently, the applied conservation management practises-mainly sheep grazing and trimming—are largely effective.

Keywords Caelifera $\cdot$ Ensifera $\cdot$ Insect diversity · Long-term $\cdot$ Nature reserve

\section{Introduction}

The majority of available studies on changes in European arthropod diversity support the assumption of a general decline in insect diversity during the last 50 years (Thomas et al. 2004; Conrad et al. 2004; Biesmeijer et al. 2006). In comparison to vertebrates and plants high decline rates are experienced by butterflies and other insects (Bourn and Thomas 2002; Schaffers et al. 2008). This is of special concern to nature conservation, since insects comprise a wide range of functional groups and trophic levels. Their declines are thought to have far-ranging consequences for ecosystem services. However, levels of decline seem to differ among insect taxa. The only available global assessment for any insect order-Odonata—indicated much lower threat levels than for most vertebrates groups 
(Clausnitzer et al. 2009). In Europe, ongoing global warming could even have positive effects on arthropods resulting in increased diversity, especially for thermobiont species (Roy et al. 2001; Warren et al. 2001; Hickling et al. 2006). These developments can best be observed through long-term studies in protected areas where general trends are not masked by land-use practices (cf. Nickel 2002; Gordo and Sanz 2005; González-Megías et al. 2008).

Effects of land-use change on local insect faunas are at least as pronounced as those of climate change, and changing agricultural practices strongly affect insect communities (cf. Maas et al. 2002; Irmler 2003; Pokivailov 2007; MüllerMotzfeld 2008). Insect conservation in Central Europe has largely been directed towards protecting habitats rather than single species, with a major focus on dry grasslands. Especially calcareous grasslands are one of the most species-rich habitats in central Europe harbouring many specialised plants and insect species (Steffan-Dewenter and Tscharntke 2002). These dry grasslands and their open structures reflect traditional land-use practices (mainly hay-making and grazing by sheep or goat (Wallis de Vries et al. 2002)), and will be encroached by shrubs and eventually trees if land use ceases entirely. This has led to major concerns on the effectiveness of reserves, which do not always receive proper conservation management (Haarmann and Pretscher 1993). It is thus of great importance to nature conservation to evaluate the efficacy of conservation measures for maintaining biodiversity.

Before the European Flora Fauna Habitat Directive (FFH) enforced large-scale reserve gazetting in the last decade (Claus and Konermann 2006), Nature Conservation Sites (NSG, "Naturschutzgebiete") were by far the most important type of nature reserves in Germany. NSGs have been at the heart of German nature conservation for almost a century, yet the few studies available suggest that they often lose diversity of rare species in spite of their protected status (Haarmann and Pretscher 1993). This is alarming, because NSGs could serve as source populations for colonisation of smaller habitats in their surroundings. In turn, biodiversity losses in reserves may be caused by ongoing changes in the surrounding landscape. Landscapelevel effects were repeatedly shown to influence insect community composition on the plot-level (Smart et al. 2006; Oliver et al. 2010) and may thus also affect the often island-like, mostly small habitat reserves.

However, comprehensive long-term monitoring data are not readily available, because studies on temporal changes in insect communities struggle with a general set of problems: Most publications are based on regionally restricted data sets. Large-scale comparisons are beginning to emerge, yet data quality for different taxa is inconsistent (Thomas et al.; Biesmeijer et al. 2006). In addition, very few studies on species' change are based on long-term observations or comparisons with historical data sets.
Where historical data are available, studies usually do not go back for more than three decades (cf. Irmler 2003; González-Megías et al. 2008; Schlicht et al. 2009). However, the most severe structural changes in the agricultural landscapes of Central Europe and other industrialised regions occurred from the 1950s to the early 1980s (Baessler and Klotz 2006; Bender et al. 2005). These may have affected insect communities that had survived centuries, or perhaps millenia, of extensive human land use (Morris 2000). Climate change has also become more pronounced in the second half of the last century, so long-term studies should ideally include data from the 1960s or earlier. Few scholars compiled reliable species lists of arthropods at that time, and where these are available the rapidly changing landscapes in Central Europe make it very hard or even impossible to rediscover former sampling sites.

Here, we present a long-term comparison for Orthoptera, which are among the preferred taxonomic groups in environmental impact assessment and conservation monitoring in Central Europe. Published data on long-term trends seem to be sparse for this group (Barker 2004), and only non-representative case studies are available (Heusinger 1980; Köhler et al. 1999). Hence, we resampled the orthopteran fauna of grassland reserves in eastern Germany, which had been surveyed by Schiemenz (1969) in the 1960s. Schiemenz provided relatively detailed descriptions of study sites and sampling methods which enabled us to directly compare orthopteran assemblages over a 40-year-period. Most sites have been and still are under some level of protection (usually NSG or equivalent). The study of Schiemenz thus provides the unique opportunity to assess changes in diversity on sites where conservation policies prevented strong alterations due to changing land use over the last five decades. Specifically, we intend to answer the following questions:

1) Are there long-term changes in orthopteran diversity or community composition of protected Central European dry grassland habitats?

2) Did changes in the surrounding landscape influence orthopteran diversity?

3) Are changes in single species occurrences related to changes in habitat structure?

4) Are current dry grassland conservation practises effective for orthopterans?

\section{Materials and methods}

Study sites and sampling

We chose 26 dry grassland sites from those where Schiemenz (1969) had compiled species lists between 1963 and 
1967 (period 1). These sites are located in an area approximately $250 \times 250 \mathrm{~km}$ in eastern Germany (Fig. 1), and comprise three different federal states: Thuringia (Thu, 8 sites, including one plot in Saxony-Anhalt), Saxony (Sax, 8 sites) and Brandenburg (Bra, 10 sites). Schiemenz gave brief descriptions of the plant communities encountered in the 1960s, which we used to rediscover the 26 plots (Table 1). All plots have southern exposures with an inclination of $0-40^{\circ}$ (mean $22^{\circ}$ ) and have a mean annual precipitation well below $750 \mathrm{~mm}$. They represent subcontinental climatic conditions within the Central European context. All plots are situated in agricultural landscapes, dominated by (annual) crops, perennial grasslands and forests, while human settlements were negligible and in at least $1 \mathrm{~km}$ distance. Truly natural habitats were absent like in most parts of Central Europe.

Each site was revisited during summer and autumn of 2008 and 2009 (period 2). Schiemenz mainly sampled Orthoptera with sweep nets (200 beats per visit), so we repeated this procedure to ensure comparability. Most of the species were identified in the field and were released after that. Just a few exceptions-including untypical Stenobothrus nigromaculatus-were determined in the lab.
Individuals were not counted. Schiemenz also identified and recorded grasshopper calls, which was repeated in 2009 as well. Bat detectors did not come in use since they were not available in Schiemenz' time. Thus, we may have missed occurrences of low chirring species such as Leptophyes albovittata Kollar 1830 or Meconema thalassinum De Geer 1773. Tetrix spp. were entirely excluded, because in period 2 mostly larvae were caught, which can not be identified with any certainty. Both Schiemenz' and our data are on the presence/absence level (no abundance), because Schiemenz provided only incomplete data on abundance in his publication, and unfortunately the original survey lists got lost.

Vegetation relevés were taken for each plot in $2008 / 2009$. We sampled one plot $(10 \times 10 \mathrm{~m})$ and recorded all occurring vascular plants and an estimate of their cover, plus supplementary information such as locality (for GPS-coordinates see Table 1), inclination and exposure. No vegetation relevés from the 1960 s were available, but comparison with Schiemenz' notes suggested that vegetation changed only slightly during the last 40 years (Table 1). Current management measures are not intensive and usually directed towards maintenance of non-woody vegetation (Table 2).
Fig. 1 Maps showing sampling sites visited in the 1960s and 2008/2009 in eastern Germany, modified from a figure by Schiemenz (1969). Sampling sites are distributed over Thuringia (Thu), Saxony (Sax) and Brandenburg (Bra). Names of sampling locations are given in German as translating did not seem reasonable (see Table 1 for exact coordinates)

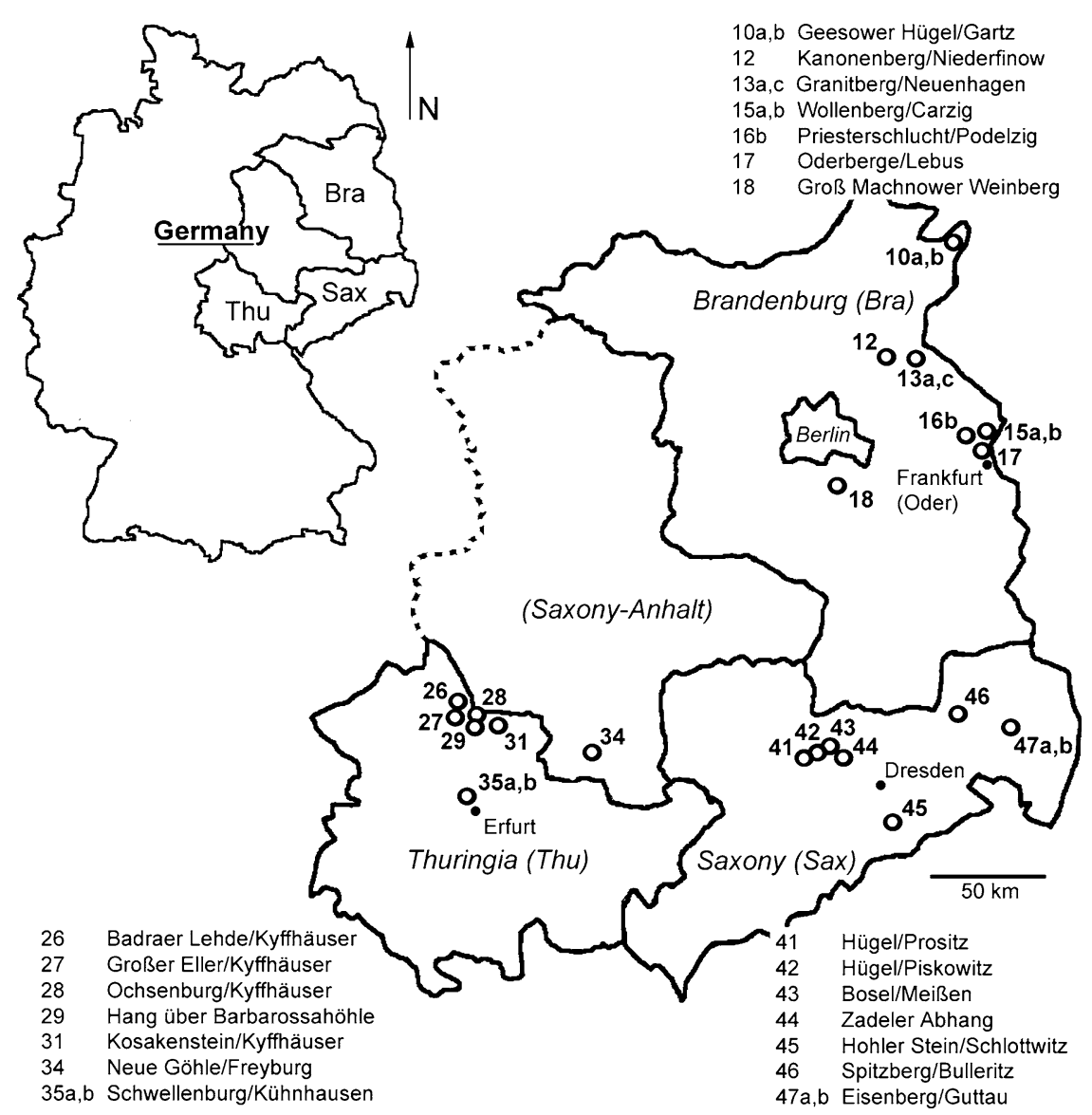




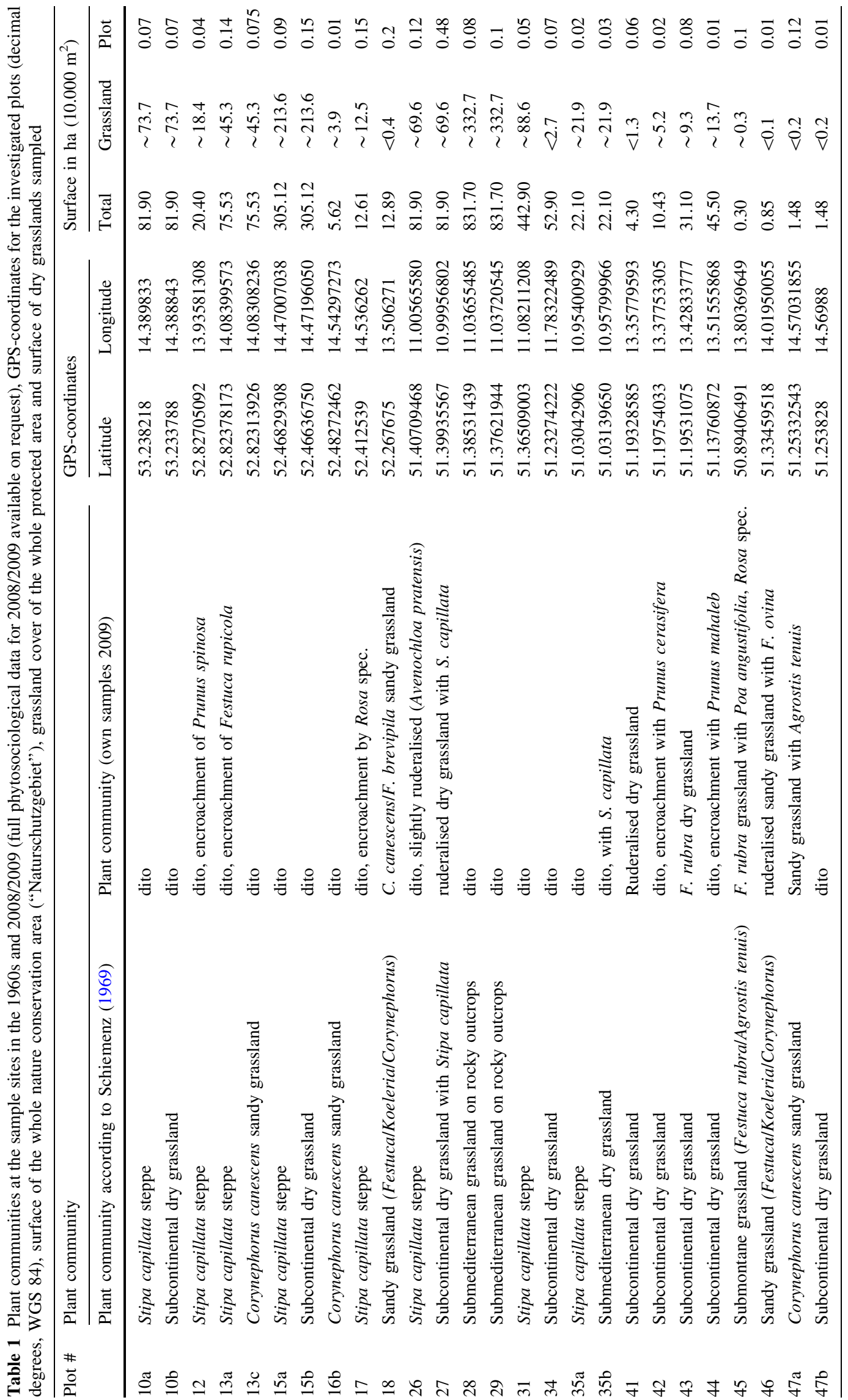




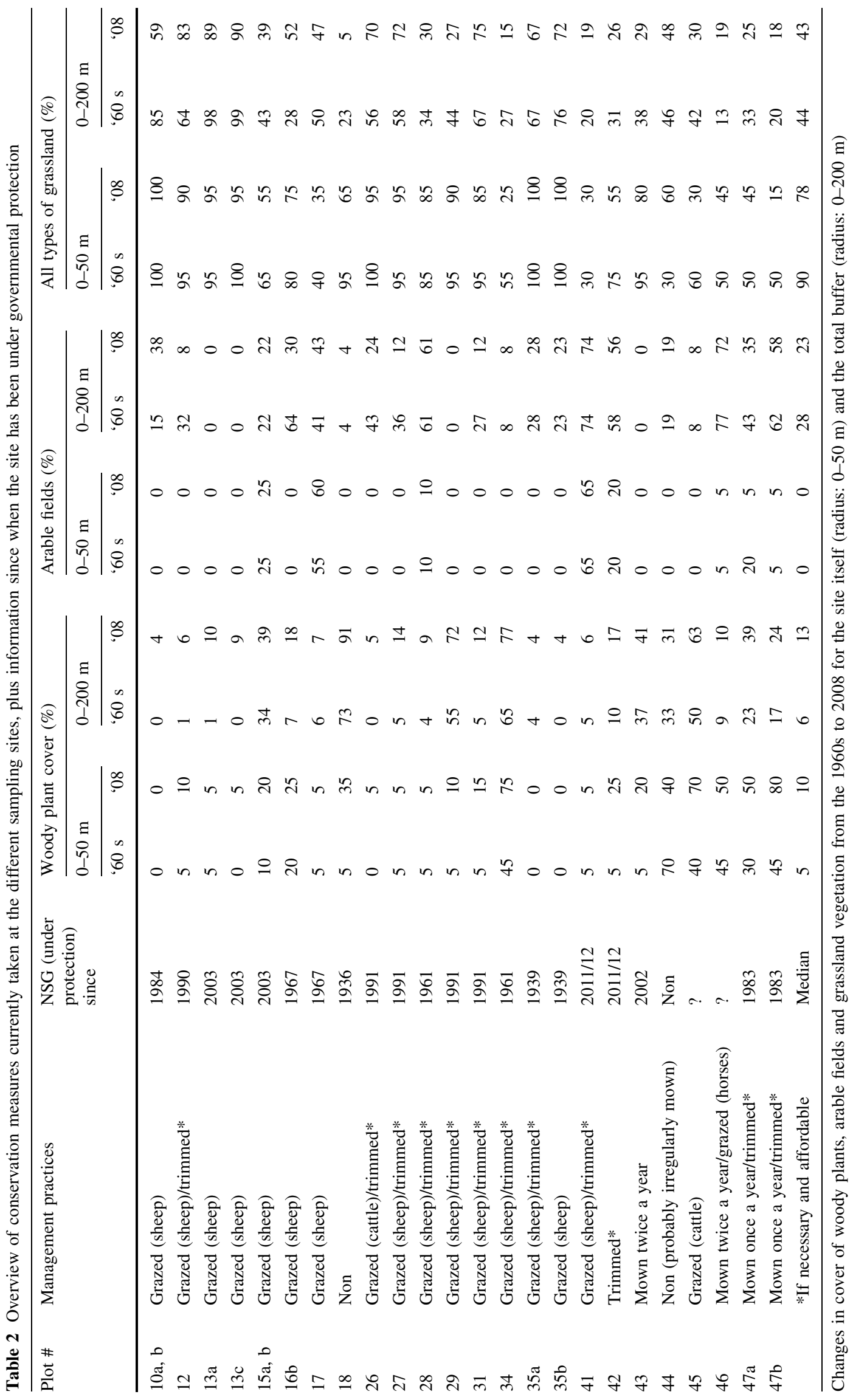


We compared the surrounding landscape of every plot using aerial photographs of the 1960s (received from Bundesarchiv Berlin) and images from 2008. We estimated cover of arable fields (A), grasslands as well as of shrubs and trees (W) expressed as a percentage (in 5\% intervals) for circular areas around the centre of the single plots using a $50 \times 50 \mathrm{~m}$ grid as a visual aid. We separately estimated vegetation cover values for three spatial sections: $0-50 \mathrm{~m}$, 50-100 $\mathrm{m}$ and 100-200 $\mathrm{m}$ (Table 2). The size of the buffer was chosen, because most Central European Orthoptera cover very limited distances during their life-time (averages $<40 \mathrm{~m}$ and maxima < $150 \mathrm{~m}$; Ingrisch and Köhler 1998). Arable fields plus shrubs and trees cover on average $50 \%$ of the whole surface around each plot in the 1960s as well as in 2008. The rest is mainly grassland of different types (settlements, streets and water account for $<5 \%$ ), which can not be distinguished on the historical aerial photographs due to similar shades on the black and white images. Analyses suggested that only changes on the plot and its immediate vicinity had effects on orthoptera communities (see "Results" below), so we refrained from analysing larger buffers.

\section{Data analysis}

We used boxplots (median and interquartile ranges) to summarise data on species richness per plot, and differences were tested with repeated measures ANOVA with period as the within-subject factor and region as betweensubject factor. Data were analysed separately for total species richness, and for those species only that are currently red-listed in at least one of the relevant federal states (Binot et al. 1998).

An initial DCA (Detrended Correspondence Analysis) showed that faunistic gradients were rather short (length of gradient $=3.7$, equivalent to less than one species turnover). We based our multivariate analysis on linear methods (McCune et al. 2002). We used PCA (Principal Components Analysis) to visualise patterns in Orthopteran communities (species centred, not standardised). Available supplementary variables were fitted with post hoc correlations on the ordination space. In correspondence to PCA, Euclidean distances were used to quantify changes in grasshopper communities among sample pairs. We used an indicator species analysis (ISA) to test for species that were significantly associated with one period or the other, and permutations were carried out separately for each region following Bakker (2008).

Vegetation data were available for period 2 only and were used to calculate weighted (square-root of plant cover) Ellenberg indicator values (Diekmann 2003) for moisture, nutrients and $\mathrm{pH}$ for current samples. Correlations between grasshopper and plant communities of period 2 were analysed with a Mantel-Test. Data were analysed using R ( R Development Core Team 2009), PC-ORD (McCune and Mefford 2006) and Canoco (ter Braak and Šmilauer 2002).

\section{Results}

\section{Species richness}

There were 35 different orthopteran species (Tetrix spp. excluded) recorded in the 1960s and 2008/2009 combined (Table 3). Schiemenz found 29 different species (13 Ensifera and 16 Caelifera) and we detected 32 in 2008/2009 (13 Ensifera and 19 Caelifera). The total number of species encountered remained unchanged over time in Thuringia and Saxony at 19 and 21, respectively. The total number of species increased for Brandenburg from 15 in period 1 to 24 in period 2.

Plot-based species richness differed among regions but not between periods (Fig. 2a). Brandenburg had the lowest species richness, with a median of 7 in period 1 and 8 in period 2. Saxony had the highest richness in the 1960s, with a median of 11 compared to 9 for Thuringia; richness decreased to 10 in Saxony and increased to 10 in Thuringia in 2008/2009. Change over time was not significant (RMANOVA, $P>0.3$, period $\times$ region interaction $P>0.2)$; differences between regions were also limited $(P=0.09)$. Almost half of the species encountered are currently threatened in at least one region (Fig. 2b). Numbers of threatened species present did neither differ between regions $(P>0.6)$ nor between periods $(P>0.9)$, but a significant period $\times$ region interaction $(P=0.02)$ confirmed that the number of threatened species present decreased in Brandenburg and Saxony but increased slightly in Thuringia.

\section{Species composition}

Only one of the species showed a significant change in terms of frequency over time according to ISA, but there were some which showed noticeable trends. The ensiferan Tettigonia viridissima occurred in only $4 \%$ of all sites in the 1960 s but was present in $31 \%$ of the recent samples $(P=0.03)$. Phaneroptera falcata (Ensifera) increased from 4 to $23 \%$, while the caeliferan Myrmeleotettix maculatus decreased from 42 to $15 \%$. The latter was the only caeliferan species that showed a marginally significant change according to ISA $(P<0.1)$. Pooling numbers for major taxonomical groups revealed a similar trend: In the 1960s, grasshopper (Caelifera) species had a median frequency of $19 \%$ (interquartile range 7-43), which decreased to $17 \%$ (IQR 8-38) in 2008/2009. The Ensifera showed an 


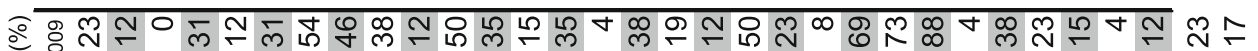
至 尊谷

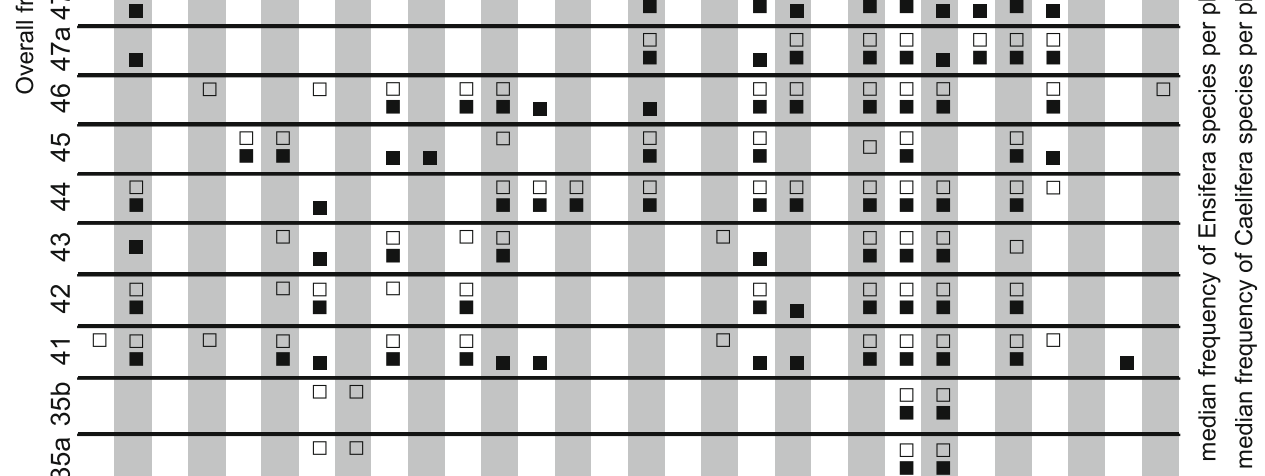
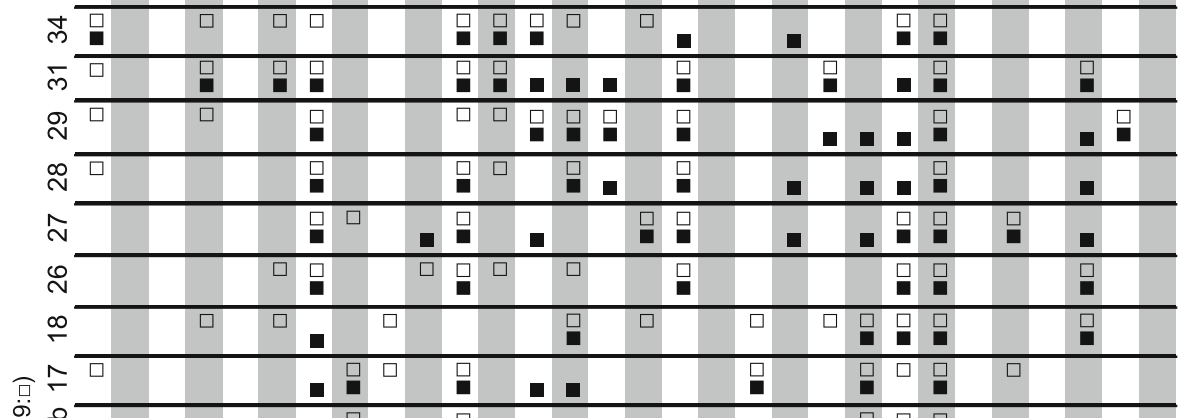

ஜे छ

ํํำ

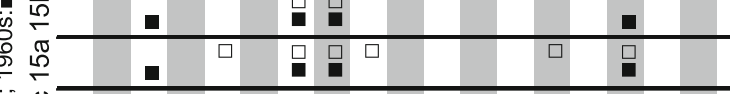
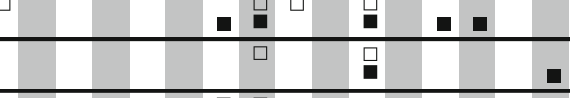

ฐ

i

2

\&

$\exists$ : $\stackrel{+}{\sim}$

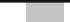

$$
\text { 믐 }
$$
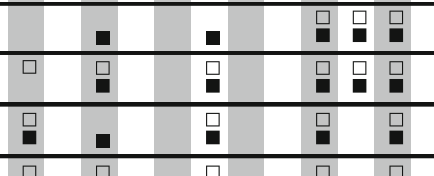

.

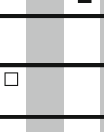

$$
\text { 9 }
$$

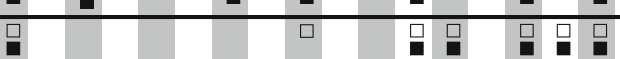

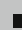

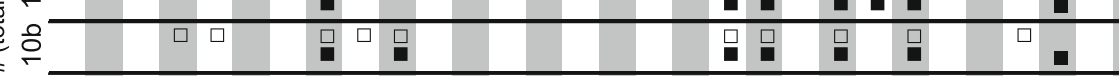

믐

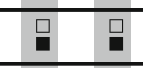

.

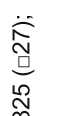


Fig. 2 Boxplots showing species richness per site for the two time periods and three regions. a total number of species; b species red-listed in at least one of the relevant federal states
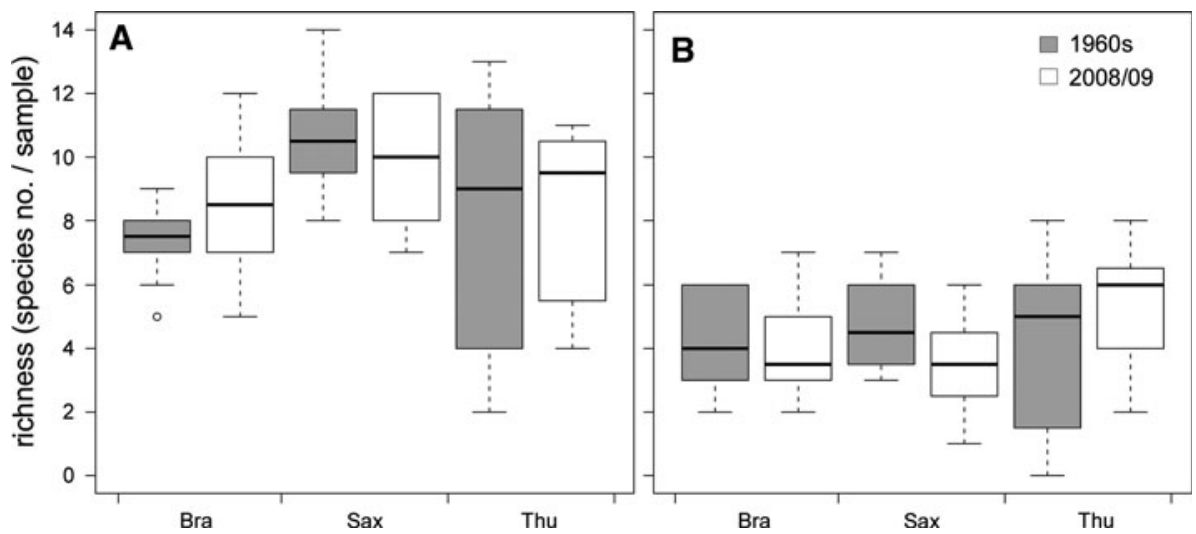

opposite trend. In period 1 each species was found at a median of $12 \%$ of all sites (IQR 4-23) while it occurred at $23 \%$ (IQR 8-37) in period 2. Thus, grasshopper in the strict sense tended to decline, while some cricket species increased. This is particularly true for Thuringia.

A multivariate analysis of species assemblages showed that regions have distinct orthopteran assemblages. In the PCA, polygons connecting the plots of samples from one region at any given time period hardly overlapped with those of other regions (Fig. 3a). The regions preserved their distinct species composition during the last 40 years as seen by the close proximity of historical and current samples for a given region in ordination space, although minor shifts in species composition were apparent. The biplot of species and samples (Fig. 3b) showed that Metrioptera bicolor (Metr_bic) and Decticus verrucivorus (Dect_ver) are typical for Brandenburg, while Stenobothrus nigromaculatus (Sten_nig) and Chorthippus vagans (Chor_vag) are restricted to Thuringia (see also Table 3). Samples from
Saxony are characterised by high incidences of Chorthippus parallelus (Chor_par), and Leptophyes albovittata (Lept_alb) is also restricted to that region.

The fitted supplementary variables showed that species richness (S) tended to be higher in Saxony (Fig. 3a). Cover of shrubs/trees at the plots (W 0-50) is also highest in Saxony, while the area of agricultural fields within a radius of $200 \mathrm{~m}$ is also largest around Saxonian plots and smaller in Thuringia and Brandenburg.

For period 2, vegetation samples were available allowing to test whether samples with a similar orthopteran community composition also had similar plant communities. The Mantel test indicated a modest, yet significant correlation $\left(\mathrm{r}_{\mathrm{M}}=0.32, P=0.0002,4999\right.$ permutations) between pair-wise orthopteran similarity (Euclidean distance) and vegetation similarity (Sörensen similarity). This justified correlating environmental information inferred from vegetation sampling in 2009 with the ordination (Fig. 3). The second PCA axis was positively associated

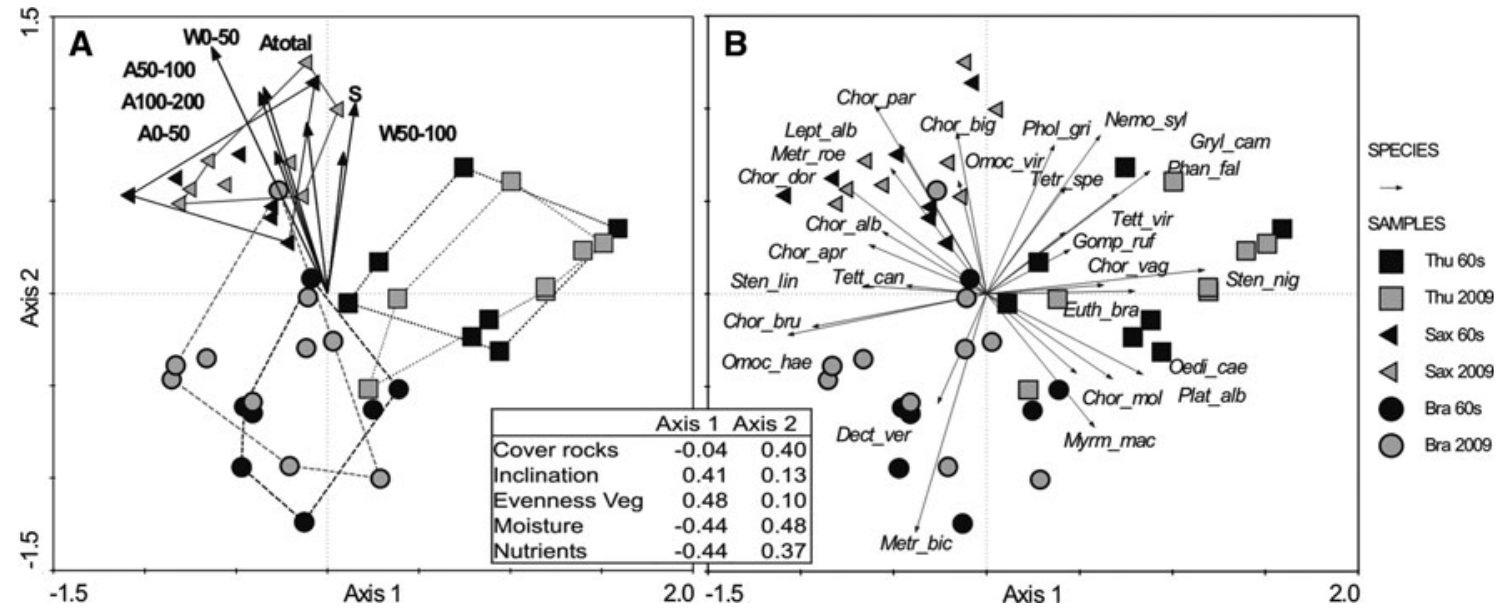

Fig. 3 PCA of the Orthoptera data for both study periods (variance/ covariance PCA, explained variance axis 1: $19.6 \%$, axis $2: 14.4 \%$, axis 3: $8.2 \%$ ). a Samples and supplementary variables: Regions and periods are indicated with different polygons. Supplementary variables were fitted post hoc on the sample plot (as vectors, threshold for post hoc correlations was $\mathrm{r}^{2}=0.11$ with either axis 1 or 2 ). b Same PCA, biplot of samples and species (only the 28 best fitting species depicted). Table: Post hoc correlations of ordination scores with environmental data available for 2009 only (those that showed $\mathrm{r}^{2}>0.10$ ) 
with the current cover of rocks, indicating that sites in Saxony today have a high cover of rock outcrops. Inclination and evenness of the vegetation were correlated with axis 1 (Fig. 3) and are therefore high in Thuringia. Weighted mean Ellenberg Indicator values for moisture and nutrient availability were negatively correlated with axis 1 and positively correlated with axis 2 , and thus pointed to the direction of the current samples from Saxony.

\section{Landscape structure and management}

Landscape structure as inferred from aerial images changed over time (Table 2). Woody cover tended to increase in all regions, but changes over time were most pronounced in Saxony, where cover on the plots increased from an already high median of 35 to $45 \%$, increases in Brandenburg were small (median 5 and $8 \%$ ) while woody plant cover in Thuringia remained stable (5\%). Cover of agricultural fields remained largely constant in the immediate surroundings of the plots, and changes in the wider buffer were also small (median cover 1960s 28\%, median cover $200823 \%, t$-test for paired samples $P=0.06$ ).

Except plots \# 18 and \# 44, all plots were under some kind of conservation management measures; most of them are grazed by sheep (Table 2) once a year. Management concepts for some sites provide trimming if necessary to prevent plots from shrub and tree encroachment, while Saxony relies on mowing and grazing by cattle. Plots that are only mown or trimmed showed a strong increase with woody plants gaining from a median of $35 \%$ cover in the 1960 s to $50 \%$ cover in $2008 / 2009$, while grazed sites remained largely constant.

Euclidean distances between Orthoptera communities of a given sample pair were moderately strongly correlated with changes (expressed in percentage cover) of shrubs/ trees on the plots ( $\mathrm{r}=0.44, P=0.025)$, while woody perennials in the immediate surroundings were less important $(\mathrm{r}=0.37, P=0.06)$, and cover in the distance class $100-200 \mathrm{~m}$ had no influence at all $(\mathrm{r}=0.07, \mathrm{~ns})$. Changes in the presence of agricultural fields had no effect for any of the three tested distance class.

\section{Discussion}

The aim of this study was to assess long-term diversity and composition changes of orthopteran assemblages in dry grassland reserves, which where under various forms of conservation management. In contrast to our expectations, these assemblages seem to be astonishingly constant, at least with respect to species presence/absence. Overall species richness did not change at all, nor did the number of species red-listed in northern Germany show any consistent change over the past 40 years. Changes in species composition existed but were relatively small, and few species showed any detectable temporal trend. Additionally, changes in composition were related to shrub encroachment on the plots, while effects of the larger landscape context were not detected.

However, trends differed among major taxonomical groups. During the past 40 years frequency decreased for grasshoppers, while it increased for the rest of the sampled orthopteran species (Ensifera). In our data set, the Ensifera comprise more generalist species and those increasing show a preference for at least partly wooded sites. The caeliferan species included a number of specialists of open soil and sparsely vegetated grasslands. One example is Myrmeleotettix maculatus, which was the only species that showed a marginal significant decline compared to the 1960s. In Germany, M. maculatus is tied to open heathland or sandy sites with sparse vegetation cover (Detzel 1998). It is also negatively associated with high shrub cover, high soil moisture and high nutrient availability (Fig. 3), and it is one of the species that underlies the correlation between changes in pair-wise species composition and shrub/tree encroachment. The decline is probably due to a slight increase of shrub/tree cover at the plots. The shrub encroachment favours another species that showed a frequency change over time, Tettigonia viridissima. This ensiferan species is today significantly more common than it used to be in the 1960s, and it indeed prefers the edges of shrubs and hedgerows in warmer habitats (Detzel 1998). Two other species showed conspicuous though not significant increases: Calliptamus italicus (Cael.) and Phaneroptera falcata (Ens.). The latter occurs in moderately open habitats with dense grass and even shrub cover, and has been spreading northwards in Germany since the 1970s. Our data reflect this general expansion. Calliptamus italicus instead is regarded as threatened in Germany (Binot et al. 1998), but the species is known for pronounced fluctuations in population size and distribution range (Sergeev and Van'kova 2008). In recent years, it seemed to re-expand on open sandy grasslands in Brandenburg, possibly as a consequence of increasing temperatures (Luthardt et al. 2009). No other species showed a clear temporal trend.

Differences between regions were pronounced. Sites in Saxony were characterised by initially high cover of shrubs/trees and agricultural fields in the surroundings, and at least as judged from the present vegetation by relatively high moisture and nutrient availability. The regions have high incidences of species which occur in intensively used grasslands and road margins (Chorthippus parallelus, Metrioptera roeselii). Metrioptera bicolor has one of its two German distribution centres in Brandenburg 
(Maas et al. 2002) and is therefore also common in our samples from that region. Preferred sites there are sandy and share the relatively open structure with the calcareous/ gypsum grasslands we visited in Thuringia. Accordingly, both regions are characterised by the presence of Oedipoda caerulescens, which also prefers open sites. Stenobothrus nigromaculatus is regarded as extremely rare and threatened in Germany, and suffers from cessation of sheep grazing in dry grasslands. The Kyffhäuser region in northern Thuringia is indeed one of the few places in Germany were populations densities are still reasonable large (Maas et al. 2002).

The lack of strong changes in species composition is probably also owed in part to the general ecology of Orthoptera. As a polyphageous insect group of low diversity (about 84 species in Germany), Orthoptera may be more resistant to environmental changes than more specialised insect groups. Maas et al. (2002) showed that the percentage of threatened (Red List) orthopteran species slightly declined in Germany during the 1990s, which concurs with our observations.

Within Central Europe, grasshopper diversity is high in regions with warm conditions such as the Rhine and Main valleys, followed by southern and eastern Brandenburg. Thus, temperature constraints certainly play a role and Orthoptera as a group may benefit from increasing temperatures. They are an example of taxa, which are less sensitive to climate change or could even benefit from it (Roy et al. 2001). Nevertheless, we found little evidence for the influence of climate change as the most thermophilous species in terms of habitat preferences are Caelifera that tended to decline rather than increase.

Overall grassland cover on the territory of eastern Germany has slightly decreased from $21 \%$ of the agricultural area to $19 \%$ (See Supplementary Material). Changes in grassland quality have been much more pronounced with intensively managed grasslands replacing other less fertile grassland types (Wesche et al. 2009). In Central Europe, dry and especially calcareous grasslands have decreased strongly in spatial extent in the last centuries (Wallis de Vries et al. 2002). The general decrease of dry grasslands can probably affect population sizes but also gene diversity in species (including grasshoppers) that are dependent on patch size as well as on patch isolation (Appelt and Poethke 1997). Additionally, source populations are on the decline, because habitat quality is apparently changing in spite of conservation, and our data show that increasing density of woody perennials may affect even potentially stable taxa such as Orthoptera (declining M. maculatus and increasing T. viridissima populations). We did, however, not find any evidence for landscape-level effects since only wood cover at the plot itself seems to have affected grasshopper communities, and even that did not influence total richness.
This is in contrast to recent studies that highlight the importance of the larger landscape context for local community composition (Gabriel et al. 2010; Oliver et al. 2010). These differences may again be related to special aspects of grasshopper biology (limited dispersal capabilities), but also to peculiarities of our analysis. Changes in the surrounding landscape were assessed by analysis of aerial imagery, which had only limited spatial and spectral resolution. This indicated only very small changes in the last 40 years, which did not explain the apparent changes in orthopteran communities.

Trends in grasshoppers are not necessarily representative for other groups (cf. Billeter et al. 2008). There are more specialized insect groups which may show faster and/ or more drastic responses to slight changes. Currently, a similar study on leafhoppers and planthoppers (Auchenorrhyncha) is in progress, which may shed light on these relationships.

The data suggest that grazing is more effective in controlling woody plants encroachment than trimming or mowing alone. This confirms conservationists preference for grazing as a management tool (Morris 2000) and the general notion that traditional land-use practices are often associated with high biological diversity in grassland habitats (Kruess and Tscharntke 2002). For dry grasslands, we conclude if a consistent and sustainable conservation management is implemented, crickets, and to a somewhat lesser extent, grasshoppers may continue to flourish as they did in the past 40 years.

Acknowledgments The study benefited from support by Viola and Hans-Joachim Clausnitzer, who offered valuable help in determining critical Orthoptera. Monika Partzsch kindly determined samples of Festuca ovina agg. Access to reserves was granted by the responsible conservation agencies. We are grateful to Heather Lessig and Sharon Cooper for linguistic corrections and to both anonymous referees for their valuable comments. This is a contribution from the joint project BioChange Germany (Cluster of Excellence "Functional Biodiversity Research"), which is funded by the State of Lower Saxony (Ministry of Science and Culture).

Open Access This article is distributed under the terms of the Creative Commons Attribution Noncommercial License which permits any noncommercial use, distribution, and reproduction in any medium, provided the original author(s) and source are credited.

\section{References}

Appelt M, Poethke H-J (1997) Metapopulation dynamics in a regional population of the blue-winged grasshopper (Oedipoda caerulescens; Linnaeus, 1758). J Insect Conserv 1:205-214

Baessler C, Klotz S (2006) Effects of changes in agricultural land-use on landscape structure and arable weed vegetation over the last 50 years. Agric Ecosys Environ 115:43-50 
Bakker JD (2008) Increasing the utility of indicator species analysis. J Appl Ecol 45:1829-1835

Barker AM (2004) Insects as food for farmland birds-is there a problem? In: van Emden HF, Rothschild MR (ed) Insect and bird interactions, Intercept Ltd, pp 37-50

Bender O, Boehmer HJ, Jens D, Schumacher KP (2005) Using GIS to analyse long-term cultural landscape change in Southern Germany. Landsc Urban Plan 70:111-125

Biesmeijer JC, Roberts SPM, Reemer M, Ohlemüller R, Edwards M, Peeters T, Schaffers AP, Potts SG, Kleukers R, Thomas CD, Settele J, Kunin WE (2006) Parallel declines in pollinators and insect-pollinated plants in Britain and the Netherlands. Science 313:351-354

Billeter R, Liira J, Bailey D, Bugter R, Arens P, Augenstein I, Aviron S, Baudry JJ, Bukacek R, Burel F, Cerny M, De Blust G, De Cock R, Diekötter T, Dietz H, Dirksen J, Dormann C, Durka W, Frenzel M, Hamersky R, Hendrickx F, Herzog F, Klotz S, Koolstra B, Lausch A, Le Coeur D, Maelfait JP, Opdam P, Roubalova M, Schermann A, Schermann N, Schmidt T, Schweiger O, Smulders MJM, Speelmans M, Sirnova P, Verboom J, van Wingerden WKRE, Zobel M, Edwards PJ (2008) Indicators for biodiversity in agricultural landscapes: a pan-European study. J Appl Ecol 45:141-150

Binot M, Bless R, Boye P, Gruttke H, Pretscher P (1998) Rote Liste gefährdeter Tiere Deutschlands. Landwirtschaftsverlag, Münster

Bourn NAD, Thomas JA (2002) The challenge of conserving grassland insects at the margins of their range in Europe. Biol Conserv 104:285-292

Bundesarchiv Berlin (All aerial photographs used from the 1960s are property of the Bundesarchiv Berlin: Finckensteinallee 63, 12205 Berlin, Germany)

Claus B, Konermann V (2006) Umsetzung von Natura 2000 in der atlantischen Region Deutschlands. Natur und Landschaft 81: 349-354

Clausnitzer V, Kalkman VJ, Ram M, Collen B, Baillie JEM, Bedjanič M, Darwall WRT, Dijkstra KDB, Dowf R, Hawking J, Karube H, Malikova E, Paulson D, Schütte K, Suhling F, Villanuevam RJ, von Ellenrieder N, Wilson K (2009) Odonata enter the biodiversity crisis debate: the first global assessment of an insect group. Biol Conserv 142:1864-1869

Conrad KF, Woiwod IP, Parsons M, Fox R, Warren MS (2004) Longterm population trends in widespread British moths. J Insect Conserv 8:119-136

Detzel P (1998) Die Heuschrecken Baden-Württembergs. Verlag Eugen Ulmer, Stuttgart

Diekmann M (2003) Species indicator values as an important tool in applied plant ecology—a review. Basic Appl Ecol 6:493-506

Gabriel D, Sait SM, Hodgson JA, Schmitz U, Kunin WE, Benton TG (2010) Scale matters: the impact of organic farming on biodiversity of different spatial scales. Ecol Letters 13:858-869

González-Megías A, Menéndez R, Roy D, Brereton T, Thomas CD (2008) Changes in the composition of British butterfly assemblages over two decades. Global Change Biol 14:1464-1474

Gordo O, Sanz JJ (2005) Phenology and climate change: a long-term study in a Mediterranean locality. Oecologia 146:484-495

Haarmann K, Pretscher P (1993) Zustand und Zukunft der Naturschutzgebiete in Deutschland. Landwirtschaftsverlag, Münster

Heusinger G (1980) Zur Entwicklung der Heuschreckenfauna im Raum Erlangen und um das Walberla-Ein Vergleich der Jahre 1946/1947 mit 1975-1978. Schriftenreihe Naturschutz und Landschaftspflege 12:53-62

Hickling R, Roy DB, Hill JK, Fox R, Thomas CD (2006) The distributions of a wide range of taxonomic groups are expanding polewards. Global Change Biol 12:450-455

Ingrisch F, Köhler G (1998) Die Heuschrecken Mitteleuropas. Westart Wissenschaften, Magdeburg
Irmler U (2003) The spatial and temporal pattern of carabid beetles on arable fields in northern Germany (Schleswig-Holstein) and their value as ecological indicators. Agric Ecosys Environ 98: $141-151$

Köhler G, Perner J, Schumacher J (1999) Grasshopper population dynamics and meterological parameters-lessons from a case study. Ecography 22:205-212

Kruess A, Tscharntke T (2002) Grazing intensity and the diversity of grasshoppers, butterflies, and trap-nesting bees and wasps. Conserv Biol 16:1570-1580

Luthardt V, Brauner O, Hoffman C, Kabus T (2009) Ausgewählte Ergebnisse der ökosystemaren Umweltbeobachtung in den Brandenburger Biosphärenreservaten. Fachbeiträge des Landesumweltamtes (Brandenburg) 112:1-24

Maas S, Detzel P, Staudt A (2002) Gefährdungsanalyse der Heuschrecken Deutschlands-Verbreitungsatlas, Gefährdungsanalyse und Schutzkonzepte. BfN-Schriften

McCune B, Mefford MJ (2006) PC-ORD 5.0. Multivariate analysis of ecological data. MjM Software Design, Gleneden Beach, Oregon

McCune B, Grace JB, Urban DL (2002) Analysis of ecological communities. MjM Software Design, Gleneden Beach, Oregon

Morris MG (2000) The effects of structure and its dynamics on the ecology and conservation of arthropods in British grasslands. Biol Conserv 95:129-142

Müller-Motzfeld G (2008) Faunenveränderungen bei Laufkäfern Mitteleuropas (Insecta, Coleoptera, Carabidae)-Indikatoren und Zeitmaß. Insecta 11:37-50

Nickel H (2002) Die Zikadenfauna der Hochmoore im Thüringer Wald heute und vor 25 Jahren (Hemiptera, Auchenorrhyncha). Naturschutzreport 19:116-138

Oliver O, Roy DB, Hill JK, Brereton T, Thomas CD (2010) Heterogeneous landscapes promote population stability. Ecol Letters 13:473-484

Pokivailov AA (2007) Long-term dynamics of orthopteran assemblages (Orthoptera) of Hissar Valley (Tajikistan). Entomol Rev 87:383-393

Roy DB, Rothery P, Moss D, Pollard E, Thomas JA (2001) Butterfly numbers and weather: predicting historical trends in abundance and the future effects of climate change. J Animal Ecol 70:201-217

Schaffers AP, Raemakers IP, Sýkora KV, ter Braak CJF (2008) Arthropod assemblages are best predicted by plant species composition. Ecology 89:782-794

Schiemenz H (1969) Die Heuschreckenfauna mitteleuropäischer Trockenrasen (Saltatoria). Faun Abh Staatl Mus Naturk Dresden 2(25):241-258

Schlicht D, Swengel A, Swengel S (2009) Meta-analysis of survey data to assess trends of prairie butterflies in Minnesota, USA during 1979-2005. J Insect Conserv 13:429-447

Sergeev M, Van'kova I (2008) Dynamics of the Italian locust Calliptamus italicus L. population in the southeast of the West Siberian Plain. Contemp Probl Ecol 1:204-209

Smart SM, Thompson K, Marrs RH, Le Duc MG, Maskell LC, Firbank LG (2006) Biotic homogenization and changes in species diversity across human-modified ecosystems. Proc R Soc B 273:2659-2665

Steffan-Dewenter I, Tscharntke T (2002) Insect communities and biotic interactions on fragmented calcareous grasslands-a mini review. Biol Conserv 104:275-284

R Development Core Team (2009) R: a language and environment for statistical computing. R Foundation for Statistical Computing, Vienna, Austria, http://www.R-project.org

ter Braak CJF, Šmilauer P (2002) Canoco 4.5 reference manual and CanoDraw for windows user's guide. Biometris, Wageningen, České Budejovicĕ

Thomas JA, Telfer MG, Roy DB, Preston CD, Greenwood JJD, Asher J, Fox R, Clarke RT, Lawton JH (2004) Comparative losses of 
British butterflies, birds, and plants and the global extinction crisis. Science 303:1879-1881

Wallis de Vries MF, Poschlod P, Willems JH (2002) Challenges for the conservation of calcareous grasslands in northwestern Europe: integrating the requirements of flora and fauna. Biol Conserv 104:265-275

Warren MS, Hill JK, Thomas JA, Asher J, Fox R, Huntley B, Roy DB, Telfer MG, Jeffcoate S, Harding P, Jeffcoate G, Willis SG,
Greatorex-Davis JH, Moss D, Thomas CD (2001) Rapid responses of British butterflies to opposing forces of climate and habitat change. Nature 414:65-69

Wesche K, Krause B, Culmsee H, Leuschner C (2009) Veränderungen in der Flächen-Ausdehnung und Artenzusammensetzung des Feuchtgrünlandes in Norddeutschland seit den 1950er Jahren. Ber Reinhold-Tüxen-Ges 21:196-210 